\title{
Integration of fishery management into the process of Maritime Spatial Planning
}

\author{
M. Kopti, R. Aps, M. Fetissov \& Ü. Suursaar \\ Estonian Marine Institute, University of Tartu, Estonia
}

\begin{abstract}
This paper discusses possible solutions to the problem of integrating fishery management into the process of Maritime Spatial Planning (MSP) and exemplifies the issue by analyzing the potential solution for the place based management of the Gulf of Riga herring fishery in the Pärnu Bay (Baltic Sea). According to the latest scientific advice, the total landings of the Gulf of Riga herring are above the Maximum Sustainable Yield (MSY) level and from the Precautionary Approach point of view, the stock is harvested unsustainably. According to the Ecosystem Approach to fisheries, the fishing capacity should be balanced with the herring stock available both at international and national level. Integration of the Gulf of Riga herring fisheries management into the Pärnu Bay MSP process means mapping and planning not only important fishing grounds but also Essential Fish Habitats and the Habitat Areas of Particular Concern. A guiding principle approach was applied to develop a shared concept of the Pärnu Bay sea area as a place based management area. In addition, the "learning by doing and seeing" methodology and "design with nature" approach were implemented and map layers visualization, supported by the BoundaryGIS geoportal, proved to be efficient tools for the participatory processes concerned. As a result, series of biophysical, socioeconomic, and jurisdictional overlays were developed and when combined together they identify in necessary detail the Pärnu Bay MSP pilot area as the sea area for place based management.
\end{abstract}

Keywords: fisheries management, place based management, MSP, Baltic Sea.

\section{Introduction}

Implementation of the generally accepted ecosystem approach to management of marine systems is widely discussed in contemporary literature. So far, however, 
the ecosystem approach has been a more widely discussed concept, but there are few examples of actual practices [1]. Crowder et al. [2] argue that the problems arise from fragmentation in the governance systems used to manage specific human uses of marine resources, together with spatial and temporal mismatches between biophysical systems and the rights, rules, and decision-making procedures created to manage human interactions with these systems. One practical way to solve these problems is suggested by Young et al. [3]: place based management, a strategy that calls for integrated management of the full suite of human activities occurring in spatially demarcated areas identified through a procedure that takes into account biophysical, socioeconomic and jurisdictional considerations.

Ehler and Douvere [1] have suggested the term "ecosystem based sea use management" that more clearly refers to the management of human uses of marine resources, including the use of marine space in such a way that ecological, social and economic objectives are achievable. Maritime Spatial Planning (MSP) is seen as a tool that enables integrated, forward-looking and consistent decision-making on the use of the sea, taking into account environmental, as well as social and economic objectives. According to the working definition by DEFRA [4], MSP is "a process for regulating, managing and protecting the marine environment that addresses the multiple, cumulative and potentially conflicting uses of the sea". To be effective, MSP requires accurate and relevant information about the marine environment as well as the dynamics of marine resource usage patterns.

European fisheries management is already strongly influenced by a spatial approach [5]: (1) output/input restrictions like setting the Total Allowable Catches (TACs) or effort quotas (days at sea) by spatial management units, (2) setting closed areas to protect commercial species at vulnerable stages in their life cycles, (3) technical conservation measures like gear regulations - especially mesh sizes - that are regionally varied to take account of differing conditions. Despite the technological transformation of the industry, focusing on fish detection and "improved" fishing equipment, fishing remains a hunting activity in which the success of the hunt is largely governed by the location and abundance of the target species at a given point in time. Therefore, better knowledge of spatial and temporal variability in the distribution of the fishable stocks is of critical importance for the economic efficiency of the fisheries.

The vast majority of Baltic Sea waters (Fig. 1) are important as fishing grounds for the fishing industry, although some marine areas are of greater economic importance than others. The annual quota (TAC) is the most commonly used management instrument of the EU conservation policy that sets the level of catch for the Baltic Sea internationally regulated fish stock units (herring, sprat, cod and salmon) by weight that the fishery as a whole should not exceed. The TAC for each stock unit is shared out into national quotas which fix the amount of fish each Member State can land.

One of the important issues the MSP should take into account is the concept of the Essential Fish Habitat (EFH), which is described as a subset of all habitats occupied by a species and is defined as those waters and substrate necessary to 
fish for spawning, breeding, feeding, or growth to maturity [6]. "Waters" are defined to include aquatic areas and their associated physical, chemical, and biological properties that are used by fish; "substrate" to include sediment, hard bottom, structures underlying the waters, and associated biological communities; "necessary" means the habitat required to support a sustainable fishery and the managed species' contribution to a healthy ecosystem. The EFH concept is gaining wider attention in fisheries management plans in different countries, aiming to identify sites that are particularly important for the maintenance of vigorous fish populations [7]. However, in the Baltic Sea fisheries management, the implementation of the concept of EFH in general and the assessment and protection of related spawning and nursery grounds of the most important commercial fishes in particular has so far attracted much less attention.

This paper discusses possible solutions to the problem of integration of fisheries management into the process of MSP and exemplifies the issue by an analysis of the potential solution for the place based management of the Gulf of Riga herring fishery in the Pärnu Bay (Baltic Sea).

\section{Material and methods}

The map of the study area is presented on Figure 1. The advice of the International Council for the Exploration of the Sea (ICES) on herring in the Gulf of Riga [8] is used as scientific factual basis for the Bayesian Belief Networks (BBNs) based fisheries system modelling and communication of the associated uncertainty.

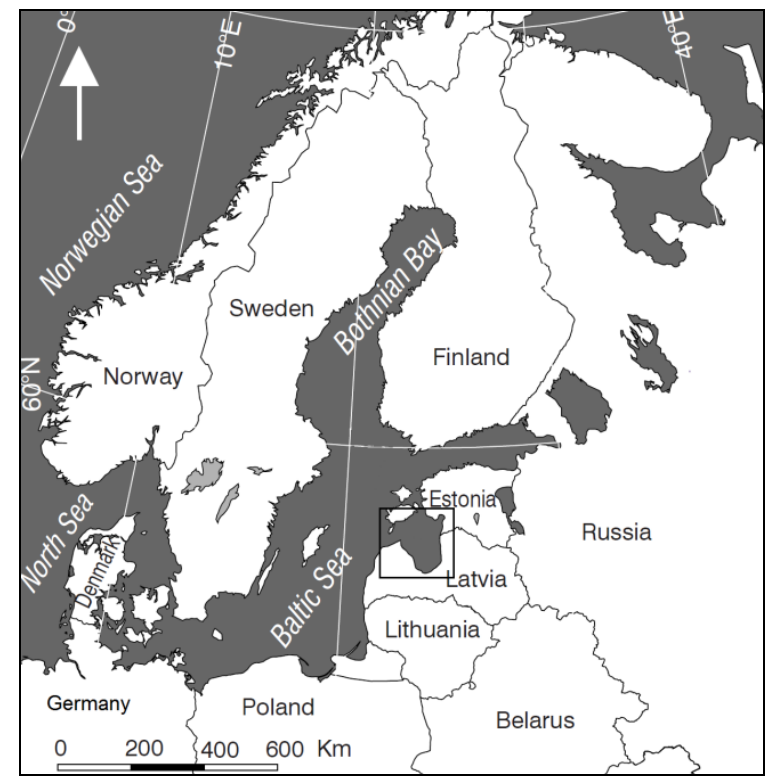

Figure 1: $\quad$ Map of the study area: Baltic Sea and the Gulf of Riga. 
BoundaryGIS geoportal (http://boundarygis.eu) [9] based BaltSeaPlan Web is used for visualization of the relevant map layers to support the participatory process aimed at the integration of fisheries management into the process of Maritime Spatial Planning. Geoportal is based on the template of Silverlight ESRI Showcase Map Application for Microsoft Visual Studio. Map layers are developed using ArcGIS Desktop and published on the ArcGIS Server. BBN based conceptual model of the Central Baltic Sea herring stock management [10] is modified accordingly and used to communicate the Gulf of Riga herring management related Bayesian uncertainty.

\section{Fishery management}

\subsection{Gulf of Riga herring fishery}

The Gulf of Riga herring is considered as a separate population of Baltic Sea herring (Clupea harengus membras, L). Herring in the Gulf of Riga is harvested by Estonia and Latvia using trawls and trap-nets (a fish trap with leader, enclosure, funnel(s) and one or two pots open on the top). According to the International Council for the Exploration of the Sea (ICES) [11] some 80-85\% of total Latvian catches are taken by trawl fishery and $15-20 \%$ by trap-nets while in Estonia the trap-net fishery is producing about $70 \%$ of the total catches and trawl fishery contributes only $30 \%$ of those. In 2008-2010, the total Gulf of Riga herring landings were respectively 37,096 t, 37,322 t and 34,948 t. Referring to the latest science advice from ICES [8], total landings of the Gulf of Riga herring are above the Maximum Sustainable Yield (MSY) level and from the Precautionary Approach point of view the herring stock is harvested unsustainably.

According to Aps et al. [10], uncertainty is an endemic condition of the Baltic Sea herring fishery management and this is true for the Gulf of Riga herring fishery management as well. Some sources of uncertainty are related to biology and fishing technique: the recruitment-environment relationship and the reduction in mean weights-at-age, uncertain ageing of fish, the problem of unaccounted fishing mortality caused by fish selection through the trawl net. The historical performance of the Gulf of Riga assessments has shown [11] an overestimation of spawning stock biomass (fishable stock) and an underestimation of fishing mortality (removal of harvested fish) since 2000, with the exception of the 2008 and 2010 assessments. Misreported catches result in additional uncertainties in the assessment.

Attempt is made to communicate the uncertainty in relationship between the fishing capacity (fleet and fixed gear), public pressure (NGOs) and the actual level of fishing mortality $(\mathrm{F})$ in relation to the $\mathrm{F}$ level corresponding to the Maximum Sustainable Yield ( $\mathrm{F}_{\mathrm{MSY}}$ ). The constructed BBN network contains two information variables: "Fishing capacity" (balanced/not balanced with the fishery resources available), and the "Public pressure" (reasoning in support of sustainable fishing - strong/weak), as well as the hypothesis variable "Harvest" 
(fishing mortality is less or equal to the $\mathrm{F}_{\mathrm{MSY}}$ / fishing mortality exceeds the $\mathrm{F}_{\mathrm{MSY}}$ ) that is presenting the fishery activities by yearly cycles (Fig. 2).

For the first year, the hypothesis variable "Harvest_1" is showing that fishing mortality exceeds $F_{M S Y}$ and this corresponds to the latest Gulf of Riga herring stock assessment by ICES [8]. Consequently, the BBN network is showing that (1) the fishing capacity is not balanced with the fish stock available, (2) the public reasoning in support of sustainable fishing is weak, (3) control and enforcement is not efficient enough, and (4) the TAC decisions are often made at the level believed not to be sustainable.

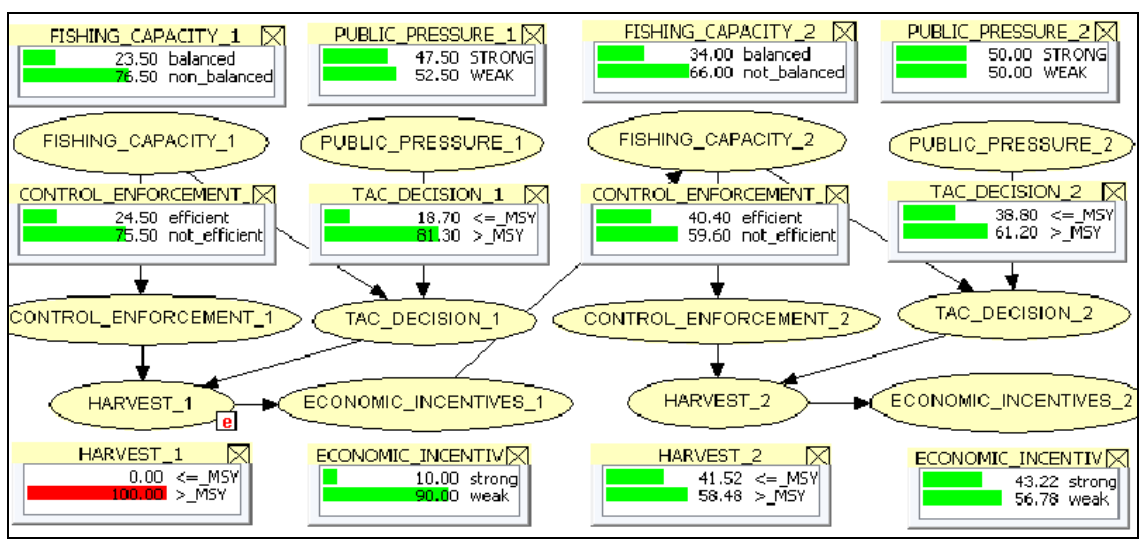

Figure 2: $\quad \mathrm{BBN}$ representing the state of the knowledge for the current status of the Gulf of Riga herring fishery management.

Traditional fishery management system is by its nature based on command and control with the regulator accepting most of the responsibility for management while rights based management relies much more on self-interest. The substantial body of published evidence shows that with non-exclusive fishing rights too, many resources are concentrated on fishing. It is believed that economic incentives like the Individual Transferable Quota (ITQ) system remarkably improve the allocation of resources because the fishing right holders have a greater vested interest in the resource and are better motivated to take more responsibility for management [12]. Therefore, if no changes in economic incentives occur in Estonia and Latvia, the fishing at the level believed to be unsustainable will most probably also continue during the years to come.

\subsection{Ecosystem approach to Gulf of Riga herring fishery}

Management based on the ecosystem approach is a multi-objective problem. The Food and Agriculture Organization (FAO) [13] definition is as follows: "An ecosystem approach to fisheries strives to balance diverse societal objectives by taking into account the knowledge and uncertainties about biotic, abiotic and human components of ecosystems and their interactions and applying an integrated approach to fisheries within ecological meaningful boundaries". 
The ecosystem approach does not in itself define the multi-objective function which is left to a lower level in the system. This implies that the objective function will vary between ecosystems in response to the human activities and the biological processes that are dominating in the ecosystem to be considered. Degnbol [14] argues that the inclusion of ecosystem considerations in fisheries management implies extensive institutional changes to challenge dramatically rising uncertainties about states and outcomes and a multiplicity of new stakeholders, interests and objectives that must be accommodated in the management institutions. Sissenwine and Mace [15] claimed that despite the conceptual elegance of the Ecosystem Approach there is a long way to go before we will be able to use it as a practical tool. Crowder et al. [16] state that although consensus has arguably been reached on the definition and goals of ecosystembased management, the slow progress toward implementation leaves few concrete examples of success. Neither single-species nor ecosystem-based fisheries management is likely to improve appreciably unless levels of fishing capacity are aligned with resource productivity [17].

\subsection{Pärnu Bay herring fishery}

The internationally allocated TAC for the Gulf of Riga herring stock is distributed into national quotas which fix the amount of fish Estonia and Latvia can land within a calendar year. The annual quota allocated to Estonia sets the level of herring catch by weight that the fishery as a whole should not exceed. The TAC allocation for the Pärnu Bay herring trap net fishery is allocated from the Gulf of Riga annual TAC allocation for Estonia and it is shared between the annual quotas for herring trawl fishery and the pound net fishery. For example, the 2011 annual quota for Pärnu Bay herring pound net fishery is 6939 tonnes.

\section{Integrating herring fishery management into the process of Pärnu Bay MSP}

\subsection{Identifying the Pärnu Bay as the place based management area}

Integrating the herring fishery management into the Pärnu Bay MSP process starts with identification of the Pärnu Bay MSP area as a place based management area. Young et al. [3] define the place based management as "...a strategy that calls for integrated management of the full suite of human activities occurring in spatially demarcated areas identified through a procedure that takes into account biophysical, socioeconomic, and jurisdictional considerations. ...By focusing on the distinctive features of individual places, tailoring management regimes to regional circumstances, and encouraging adaptive management and social learning, place-based management of marine ecosystems offers a constructive means for dealing with the uncertainties associated with complex, heterogeneous, and dynamic systems. By clarifying the meaning of rules as applied to specific places, enhancing monitoring, adjusting competing uses to alleviate conflicts, and reducing the incentives to cheat, a 
place-based approach can also make it easier to implement management procedures".

During the BaltSeaPlan Pärnu Bay Pilot Project stocktaking phase, the biophysical conditions (distinctive assemblages/communities of marine organisms) have been identified. Map layers on human uses of the Pärnu Bay have been developed. These overlays identified the spatial distribution of tourism, fishing, shipping, and planned wind farms (Fig. 3). Jurisdictional overlays have been developed with the aim to delineate areas covered by existing management arrangements under the Estonian legal acts such as Planning Act, Building Act, Ports Act, Maritime Safety Act, Water Act, Fishing Act, Economic Zone Act, Nature Conservation Act, Environmental Monitoring Act, Environmental Supervision Act, and the Public Information Act.

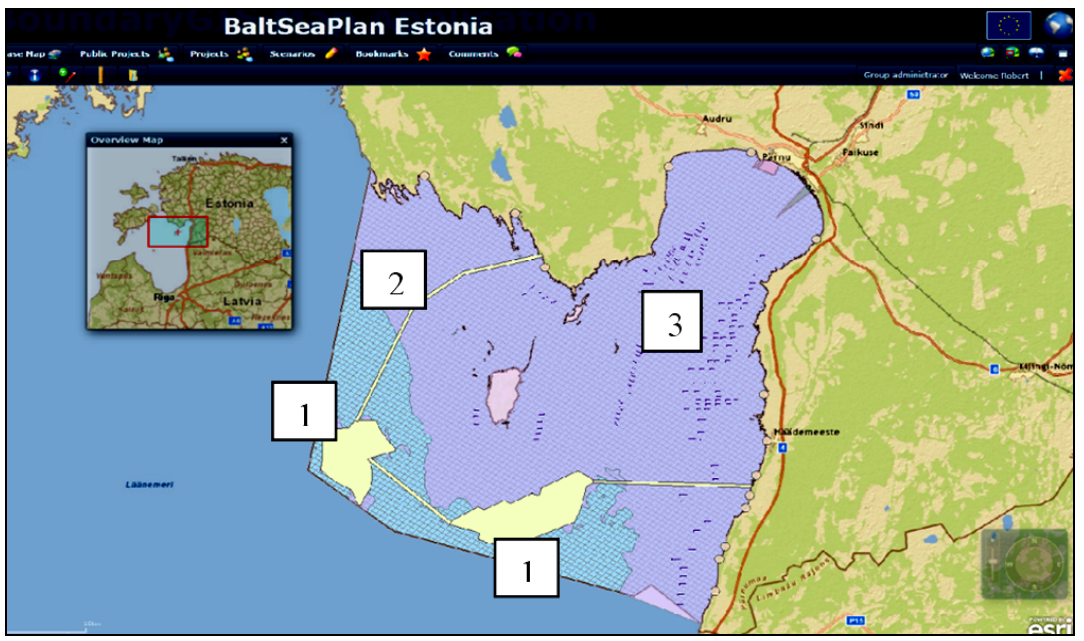

Figure 3: $\quad$ Planned wind park areas (1), submerged cables (2), trap net fishing area (3) as integrated in the BaltSeaPlan Estonia interactive web window (Pärnu Bay, Gulf of Riga, Baltic Sea).

Combining the series of these biophysical, socioeconomic, and jurisdictional overlays identify in necessary detail the Pärnu Bay MSP pilot area as the sea area for place based management. In developing maps for the Pärnu Bay MSP process, the key variables, including the biophysical and socioeconomic components, were demarcated and the possible conflicts between the inherently spatial ecological component and the human component were identified.

\subsection{The shared vision and planning concept}

The planning concept for Pärnu Bay MSP was discussed at the stakeholder meeting in May 2011. Discussion was supported by the BoundaryGIS based BaltSeaPlan Web map layers visualization. The stakeholder meeting agenda was building on the concepts and language of the Planning with Water Guidebook 
[18]. According to the Guidebook, a good planning concept should integrate the aspects of actors (investors, businesses, government agencies, users, residents, NGO's), areas (decisions about areas of different scale) and flows (energy, waste materials, traffic and water).

Building on the methodology of the Guidebook, the discussion focuses on three topics: (1) turn areas into places (use existing site qualities of nature and cultural history to develop the area into a place with identity and beauty), (2) turn flows into chains (connect flows elements by responsible management), and (3) turn actors into participants (aim at involving stakeholders in the planning process). Furthermore, a "guiding principle approach" was applied to develop a shared vision and concept that includes Pärnu Bay sea area as a place based management area while the "learning by doing and seeing" methodology and "design with nature" approach were implemented and, supported by the BoundaryGIS based map layers visualization, focusing on that particular sea and coastal area as a source of inspiration for achieving identity.

The Pärnu Bay MSP related stakeholder discussion was structured according to the Two Networks Strategy [18] considering the (1) traffic network as a carrier of fishery, trade and commerce, mass recreation and most types of modern agriculture, and (2) the water network as a carrier of functions like quiet recreation and wildlife. At the same time, the two networks are the carrying structures of a zoning principle that goes from a quiet and clean green/blue area to a more polluted and noisy business area. Central to the Two Networks Strategy is contrasting the worlds of dynamics and tranquillity by emphasizing the slow-lane and fast-lane polarity (slow-lane is the less dynamic zone, quiet and clean, while the fast-lane is the world with dynamic economic activities, high-speed traffic and rapid spatial changes). As a consequence, the integration of the herring fishery into the Pärnu Bay MSP process has started at the early stage of planning by involving the stakeholders in the discussions on the shared vision and the planning concept itself. The stakeholders reached a consensus on the most general shared visionary and conceptual definitions of the "Pärnu Bay as a cradle of marine life including fish" at the meeting in May 2011.

As a result of the implemented "learning by doing and seeing" and "design with nature" approaches and supported by the BoundaryGIS based map layers visualization, the stakeholders also developed a conceptual image of the Pärnu Bay area that resembles the "Blue sea in the green crescent" concept. The green coastal land is roughly divided into a fast lane road traffic network (including the Via Baltica international road network) with the Port of Pärnu as a hub connecting the road and maritime transport networks in the area, and the slow lane - a quieter and cleaner area along the coast of the Pärnu Bay. The Kihnu Island in the Pärnu Bay was certainly considered belonging to the slow lane with its emerging image that resembles the "Green star in the blue sea". The tourism industry is interested in the consensual decision on the "Clear Horizon Principle" to avoid the potential negative influence of the visual pollution caused by the wind park. The fishing community and the NGOs are worried about an electromagnetic radiation field generated by the wind farm's electric current 
carrying cables, and they are seeking consensus on a decision guaranteeing a cabling solution with minimal or no electromagnetic field.

\subsection{Integrating the herring fishery into the Maritime Spatial Planning}

According to the Fishery Act of Estonia and based on the condition of fishery resources, the Government of Estonia establishes, by counties or internal water bodies the fishing opportunities on the basis on a fisher's fishing permit for the year for which the permit is applied. The shallow Pärnu Bay herring fishery is a trap net fishery only because it is prohibited to catch fish with a trawl below the 20 meter isobath. A trap is fishing gear with the catching principle where the fish is attracted to the trap or its part where it is easy to enter but difficult to find a way out. A trap net is a fish trap with a leader, wings (which form an enclosure), with one or several funnels, with the belly or bellies closed on the top.

Furthermore, fishing shall be performed pursuant to fishing rights that, in the case of the Pärnu Bay herring, are subject to a fee. Now, a person who is registered in the commercial register as an entrepreneur and whose area of activity entered in the commercial register is fishing may fish for herring with commercial fishing gear (trap net) on the basis of a fishing permit provided that this person is duly observing all the spatial and temporal restrictions in force. The number and the positions of the individual trap nets in the Pärnu Bay are historically established (Fig. 3).

Technically speaking, integrating the Pärnu Bay herring fishery into the process of MSP means amending the Estonian Fishing Rules and/or some other legal acts by adding some more herring fishery related spatial/temporal restrictions. For example, the sea areas planned for wind park development will most probably be closed at least for some fisheries in the Pärnu Bay planning area and this will introduce changes into the existing jurisdictional overlay.

\subsection{Essential Fish Habitats}

At the meeting in May 2011 the stakeholders underlined in relation to the herring fishery the importance of protecting of the herring's spawning grounds in the Pärnu Bay, which are sensitive to both increasing anthropogenic pressure and projected climate change induced environmental regime shifts [10, 19]. The latter applies to fish via changes in thermohaline, light and nutritional conditions, as well as through physical disturbance and destruction of spawning grounds during extreme storms [20]. Currently, planners have access to the highly reliable long term data on the spawning grounds and the herring's larvae production in the Pärnu Bay [21], as well as voluminous assessments of climate change related effects on fisheries [22]. These data constitute the important factual basis for potential implementation of the concept of Essential Fish Habitat (EFH) in relation to the Pärnu Bay herring. The EFH approach is also well supported by the shared concept of Pärnu Bay as a cradle for herring. Spring spawning herring spawning grounds in the Pärnu Bay (Fig. 4) should be considered by planners as a Habitat Areas of Particular Concern (HAPCs) that 


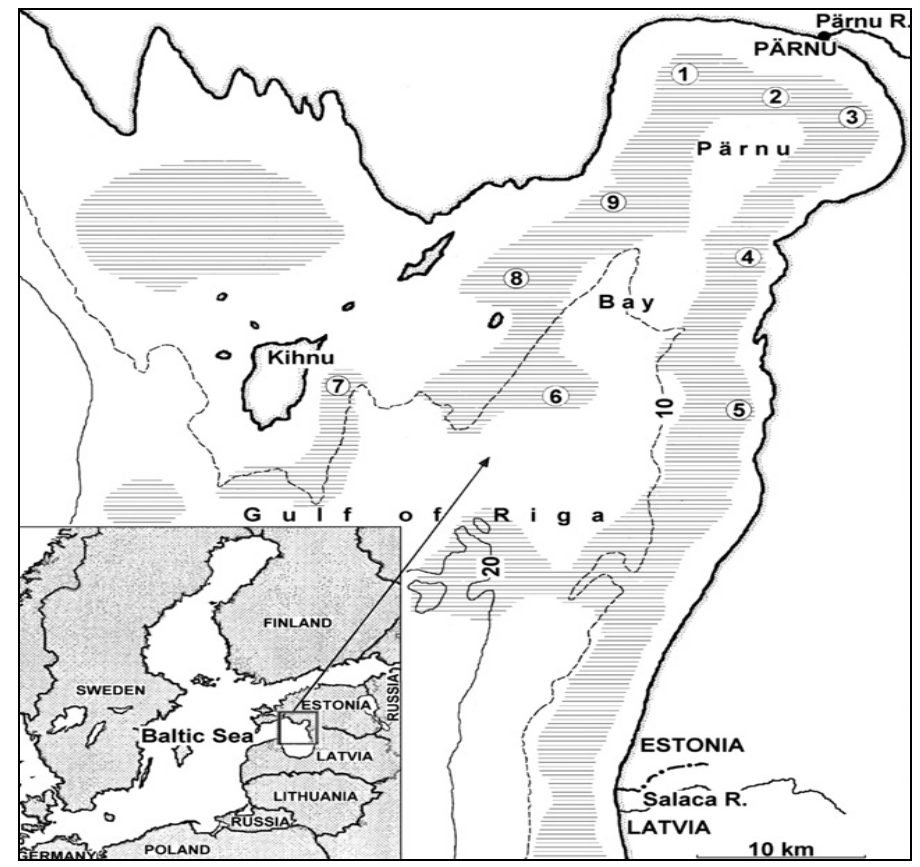

Figure 4: Spawning grounds (hatched) of the spring spawning herring in the NE Gulf of Riga and the sampling stations (1-9) [21].

are defined as subsets of the EFH which are particularly susceptible to humaninduced degradation and ecologically especially important [6].

\section{Conclusions}

According to the latest scientific research, the total landings of the Gulf of Riga herring are above the Maximum Sustainable Yield level and from the Precautionary Approach point of view, the herring stock is harvested unsustainably. Therefore, according to Ecosystem Approach to fisheries, the fishing capacity should be balanced with the available herring stock both at international and national levels. It is believed that economic incentives like the Individual Transferable Quota system may remarkably improve the allocation of resources because the fishing right holders have a greater vested interest in the resource and are better motivated to take more responsibility for management. Therefore, if appropriate economic incentives will not be introduced in Estonia and Latvia, then the unsustainable herring fishing problem in the Gulf of Riga is likely to persist for years to come.

Integration of the Gulf of Riga herring fisheries management into the Pärnu Bay MSP process means mapping and planning not only important fishing grounds but also Essential Fish Habitats and the Habitat Areas of Particular Concern. A guiding principle approach applied to develop a shared vision and 
concept of the Pärnu Bay sea area as a place based management area. In addition, the implemented "learning by doing and seeing" methodology and "design with nature" approach and, the BoundaryGIS supported map layer visualization proved to be efficient tools for the participatory processes concerned. As a result, series of biophysical, socioeconomic, and jurisdictional overlays have been developed and when combined, they identify in necessary detail the Pärnu Bay MSP pilot area as the sea area for place based management.

\section{Acknowledgements}

This study was supported by the Estonian Target Financing Programme SF0180104s08, ESF Grant No 7609, and by the EU Baltic Sea Region Programme 2007-2013 Project: "Introducing Maritime Spatial Planning in the Baltic Sea (BaltSeaPlan)" and the EU 7FP Project GAP2 "Bridging the gap between science, stakeholders and policy makers" (Phase 2 - Integration of evidence-based knowledge and its application to science and management of fisheries and the marine environment).

\section{References}

[1] Ehler, C. \& Douvere, F., Marine Spatial Planning: a step-by-step approach toward ecosystem-based management. IOC Manual and Guides No. 53, ICAM No. 6. Paris: UNESCO, 99 pp., 2009.

[2] Crowder, L., Osherenko, G., Young, O., Airaime, S., Norse, E., Baron, N., Day, J., Douvere, F., Ehler, C., Halpern, B., Langdon, J., McLeod, K., Ogden, J., Peach, R., Rosenberg, A. \& Wilson, J., Resolving mismatches in US ocean governance. Science, 313, pp. 617-618, 2006.

[3] Young O.R., Osherenko G., Ogden J. et al., Solving the crisis in ocean governance: place-based management of marine ecosystems. Environment, 49, pp. 20-32, 2007.

[4] DEFRA. Managing Our Marine Resources: the Marine Management Organization. Department of Environment, Food and Rural Affairs (Defra), London, UK, 38 pp. 2009.

[5] Symes, D., Marine Spatial Planning: A Fisheries Perspective. Report to English Nature. Unpublished, 35 pp., 2005.

[6] NOAA. A Primer for Federal Agencies, Essential Fish Habitat: New Marine Fish Habitat Conservation Mandate for Federal Agencies. National Marine Fisheries Service, Southwest Regional Office, Long Beach, CA. 8 pp., 1998.

[7] Bergström, L., Korpinen, S., Bergström, U. \& Andersson, A., Essential fish habitats and fish migration patterns in the Northern Baltic Sea. BALANCE Interim Report No. 29, 33 pp., 2007.

[8] ICES. ICES Advice 2011, Book 8, pp. 28-36, 2011.

[9] Fetissov, M. \& Aps, R., BoundaryGIS geoportal: advanced platform in support of participatory processes. Ravage of the Planet III. Book Series: 
WIT Transactions on Ecology and The Environment, 148, WIT Press: Southampton, Boston: pp. 505-516, 2011.

[10] Aps, R., Fetissov, M., Holmgren, N., Norrström, N. \& Kuikka, S., Central Baltic Sea herring: effect of environmental trends and fishery management. Y. Villacampa, C.A. Brebbia (Eds.). Ecosystems and Sustainable Development VIII, WIT Press, pp. 69-80, 2011.

[11] ICES. WGBFAS Report 2011, Annex 9 - Stock Annex, Herring GoR, pp. 588-595, 2011.

[12] Scott, A., Introducing Property in Fishery Management. In: R. Shotton (Ed.). FAO Fisheries Technical Paper 404/1. Rome, pp. 1-13, 2000.

[13] FAO. The Ecosystem Approach to Fisheries. Technical Guidelines for Responsible Fisheries, 4, Suppl. 2, FAO, Rome. 121 pp., 2003.

[14] Degnbol, P., The ecosystem approach and fisheries management institutions: the noble art of addressing complexity and uncertainty with all onboard and on a budget. IIFET 2002 paper no 171, 11 pp., 2002.

[15] Sissenwine, M.P. \& Mace, P.M., Governance for Responsible Fisheries: an Ecosystem Approach. Paper presented to Reykjavik Conference on Responsible Fisheries in the Marine Ecosystem. Iceland, 1-4 October 2001, 29 pp., 2001.

[16] Crowder, L.B., Hazen, E.L., Avissar, N., Bjorkland, R., Latanich, C. \& Ogburn, M.B., The Impacts of Fisheries on Marine Ecosystems and the Transition to Ecosystem-Based Management. Annu. Rev. Ecol. Evol. Syst., 39, pp. 259-278, 2008.

[17] Mace P.M., A new role for MSY in single-species and ecosystem approaches to fisheries stock assessment and management. Fish and Fisheries, 2, pp. 2-32, 2001.

[18] van Hilten, H., Andreasson, J., Bottenberg, H., Clegg, E. \& Weldstra, W., The PURE Guidebook on planning with water. PURE North Sea INTERREG III B Project. 98 pp., 2006.

[19] Suursaar, Ü., Kullas, T., Kovtun, A., Torn, K. \& Aps, R., Climate change induced decadal variations in hydrodynamic conditions and their influence on benthic habitats of the Estonian coastal sea. Ravage of the Planet III. Book Series: WIT Transactions on Ecology and The Environment, 148, WIT Press: Southampton, Boston: pp. 427-438, 2011.

[20] Suursaar, Ü., Kullas, T., Otsmann, M., Saaremäe, I., Kuik, J. \& Merilain, M., Cyclone Gudrun in January 2005 and modelling its hydrodynamic consequences in the Estonian coastal waters. Boreal Environment Research, 11, pp. 143-159, 2006.

[21] Ojaveer, E., Arula, T., Lankov, A. \& Shpilev, H., Impact of environmental deviations on the larval and year-class abundances in the spring spawning herring (Clupea harengus membras L.) of the Gulf of Riga (Baltic Sea) in 1947-2004. Fisheries Research, 107, pp. 159-168, 2011.

[22] ICES. Report of the ICES/HELCOM Working Group on Integrated Assessments of the Baltic Sea (WGIAB), 16-20 March 2009, Rostock, Germany. ICES CM 2009/BCC:02. 81 pp., 2009. 